\title{
HUBUNGAN ANTARA EFIKASI DIRI DAN RELIGIUSITAS DENGAN INTENSITAS PERILAKU MENYONTEK SISWA DI MTS MAZRA'ATUL ULUM PACIRAN-LAMONGAN
}

\author{
Atik Halimatul Ula \\ Achmad Khudori Sholeh \\ Fakultas Psikologi \\ Universitas Islam Negeri (UIN)Maulana Malik Ibrahim Malang \\ Jl. Gajayana 50 Malang Telp. 0341-558916
}

\begin{abstract}
Abstrak :Kata menyontek dalam kegiatan akademis sering terjadi dalam dunia pendidikan. Oleh sebab itu, menyontek menjadi salah satu fenomena yang muncul menyertai proses belajar siswa di sekolah. Dengan semakin maraknya perilaku menyontek ini, maka perlu meningkatkan faktor-faktor yang menurunkan perilaku menyontek ini antara lain yaitu dengan meningkatkan efikasi diri dan religiusitas siswa.Penelitian ini merupakan penelitian kuantitatif dengan pendekatan deskriptif korelatif, yaitu mencari hubungan antara efikasi diri dan religiusitas dengan intensitas perilaku menyotek pada siswa. Subjek dalam penelitian ini adalah 71 siswa. Pengambilan data dalam penelitian ini menggunakan skala efikasi diri, religiusitas dan intensitas perilaku menyontek. Skala efikasi diri terdiri dari 22 aitem dengan $a=0.844$, skala religiusitas terdiri dari 25 aitem dengan $\mathrm{a}=0.897$ dan untuk skala perilaku menyontek terdiri dari 28 aitem dengan $\mathrm{a}=0.921$. Analisis data yang digunakan untuk mengetahui hubungan negatif antara efikasi diri dan religiusitas dengan intensitas perilaku menyontek adalah uji statistik parametrik teknik analisis regresi berganda linier. Hasil analisis tersebut menunjukkan adanya hubungan negatif dan signifikan antara efiaksi diri dan religiusitas dengan intensitas perilaku menyontek pada siswa MTs Mazra'atul Ulum Paciran-Lamongan. Hal tersebut ditunjukkan oleh angka koefesien korelasi ( $r x y)$ sebesar 0.493 dengan $P=0.000(p<0.05)$. sehingga hipotesis yang menyatakan ada hubungan negatif antara efikasi diri dan religiusitas dengan intensitas perilaku menyontek dapat diterima. Berdasarkan penelitian ini dapat disimpulkan bahwa terdapat hubungan negatif antara efikasi diri dan religiusitas dengan intensitas perilaku menyontek pada siswa MTs Mazra'atul Ulum Paciran-Lamongan.Semakin positif efikasi diri dan religiusitas maka semakin rendah intensitas perilaku menyontek dan sebaliknya.
\end{abstract}

Kata Kunci : Efikasi Diri, Religiusitas, Intensitas, Perilaku Menyontek, Siswa

PSIKOISLAMIKA. Jurnal Psikologi Islam (JPI) copyright @ 2014 Laboratorium Penelitian, Kajian Psikologi Islam dan Penerbitan. Volume 11. Nomor 1, Tahun 2014

\section{PENDAHULUAN}

Mazra'atul Ulum merupakan salah satu lembaga pendidikan yang terdiri dari beberapa jenjang pendidikan yang diantaranya adalah Madrasah Tsanawiyah (MTs) atau setingkat dengan Sekolah Menengah Pertama (SMP). Lembaga pendidikan yang berbasiskan agama Islam yang bertujuan melejitkan potensi diri serta melahirkan intelektual muslim.
Selain kegiatan belajar mengajar, siswa MTs Mazra'atul Ulum juga mengikuti kegiatan ekstrakulikuler yang diadakan oleh madrasah. Dengan kegiatan yang padat siswa tentu harus sebisa mungkin mengatur jadwal kegiatannya sehari-hari. Karena kalau tidak siswa akan kewalahan dengan segudang kegiatan yang ada. Dengan banyaknya aktivitas, tak jarang dari siswa sudah mulai malas 
belajar lagi pada malam hari karena sudah lelah dengan aktivitas yang sangat padat.Siswa sudah lelah dan lebih memilih untuk bertistirahat atau sekedar menonton televisi dan bersantai.Karena siswa tidak belajar pada waktu malam, ketika ada ulangan atau tes berlangsung siswa tidak siap menghadapai tes tersebut.Dengan begitu siswa lebih memilih jalan pintas dengan meminta jawaban dari temannya atau menyontek.

Dalam Kamus Bahasa Inggris (Echols \& Shadily, 2003) kata menyontek atau menjiplak disebut dengan istilah Cheating. Hal ini sesuai dengan artikel yang ditulis oleh Alhadza, kata menyontek sama dengan Cheating. Beliau mengutip pendapat Bower, yang mengatakan Cheating adalah perbuatan yang menggunakan cara-cara yang tidak sah untuk tujuan yang sah atau terhormat yaitu mendapatkan keberhasilan akademis atau menghindari kegagalan akdemis (Alhadza dalam Alawiyah, 2011:21).

Beberapa data yang memprihatinkan adalah Survey nasional yang dilakukan oleh Josephson Institute of ethics di Amerika pada tahun 2006 (Paris S Strom; Robert D Stromdengan: 2007 dalam Hartanto, 2010) dengan responden 36.000 siswa Sekolah Menegah Pertama menemukan 60\% siswa menerima dan mengakui pernah mencontek pada saat ujian dan pengerjaan tugas. Terjadi peningkatan sebesar $10 \%$ dalam kurun waktu 20 tahun. $95 \%$ diantaranya mengaku bahwa tidak pernah ketahuan ketika mencontek.

Adapun faktor internal yang diduga dapat meningkatkan dan menurunkan perilaku menyontek pada kalangan siswa Sekolah Menengah Pertama adalah keyakinan dalam diri siswa akan kemampuan diri sendiri (self-efficacy) serta religiusitas siswa itu sendiri.

Makna religiusitas menurut Fetzer (dalam Farhah, 2011:19) yaitu seberapa kuat individu penganut agama merasakan pengalaman beragama sehari-hari, mengalami kebermaknaan hidup dengan beragama, mengekspresikan keagamaan sebagai sebuah nilai, meyakini ajaran agamanya, memaafkan, melakukan praktek beragama (ibadah) secara menyendiri, mendapat dukungan penganut sesama agama, mengalami sejarah keberagamaan, komitmen beragama, mengikuti organisasi atau kegiatan keagamaan, dan meyakini pilihan agamanya.

Perilaku menyontek juga bisa dipengaruhi oleh religiusitas siswa yang kurang. Dengan mengenyang pendidikan dan pengajaran yang berbasis agama dan lingkungan yang mendukung, siswa harusnya mampu dan memiliki sikap religiusitas yang tinggi.
Fakta diatas menunjukkan bahwa perilaku menyontek merupakan suatu permasalahan yang menarik untuk dikaji lebih lanjut. Berpijak dari uraian diatas, maka penulis tertarik untuk melakukan penelitian dengan tema: Hubungan antara Efikasi Diri dan Religiusitas dengan Intensitas Perilaku Menyontek pada Siswa MTs Mazra'atul Ulum Paciran-Lamongan.

\section{TINJAUAN PUSTAKA Efikasi Diri}

Bandura (1998:3) menyebutkan "Perceivedselfefficacy refers to beliefs in one's capabilities to organize and execute the courses of action required to produce given attainments". Dari definisi tersebut dapat dipahami bahwa efikasi diri merupakan keyakinan seseorang akan kemampuannya untuk mengatur dan melaksanakan serangkaian tindakan yang dibutuhkan untuk menghasilkan hasil yang ingin dicapai. Efikasi diri merupakan keyakinan individu terhadap kemampuannya bahwa setiap orang mempunyai kemampuan untuk mengatur dan menyelesaikan tugas tertentu.

Ketika self-efficacy tinggi, kita merasa percaya diri bahwa kita dapat melakukan respon tertentu untuk memperoleh reinforcement. Sebaliknya apabila rendah, maka kita merasa cemas bahwa kita tidak mampu melakukan respon tersebut.Persepsi tentang self-efficacy bersifat subjektif dan khas terhadap bermacam-macam hal. Walaupun persepsi tentang self-efficacy dapat memprediksi tingkah laku secara baik, namun persepsi tersebut dipengaruhi oleh perasaan umum dari self-efficacy sendiri.Persepsi self-efficacy dapat mempengaruhi tantangan mana yang harus diatasi (dihadapi) dan bagaimana menampilkan perilaku yang lebih baik.

Bandura (1998:42) mengungkapkan bahwa efikasi diri terdiri dari tiga dimensi, yaitu:

a. Level: Berhubungan dengan taraf kesulitan tugas. Dimensi ini mengacu padataraf kesulitan tugas yang diyakini individu akan mampu mengatasinya.Tingkat efikasi diri seseorang berbeda satu sama lain. Tingkatan kesulitandari sebuah tugas, apakah sulit atau mudah akan menentukan efikasi diri(Bandura, 1998:42).

b. Strenght : Dimensi ini berkaitan dengan kekuatan penilaian tentangkecakapan individu. Dimensi ini juga mengacu pada derajat kemantapanindividu terhadap keyakinan yang dibuatnya. Kemantapan ini yangmenentukan ketahanan dan keuletan individu dalam usaha. (Bandura,1998:44). 
c. Generality: Merupakan suatu konsep bahwa efikasi diri seseorang tidakterbatas pada situasi yang spesifik saja. Dimensi ini mengacu pada variasisituasi di mana penilaian tentang efikasi diri dapat ditetapkan.

\section{Religiusitas}

Religiusitas berasal dari bahasa latin religi. Religi asalnya adalah relegere yang berarti mengumpulkan atau membaca.Sedangkan kata religare berarti mengikat.Agama mengandung arti kata ikatan yang harus dipegang dan dipatuhi manusia. Agama, dalam pengertian Glock \& Stark (dalam Djamaludin \& Fuat, 2011:76), adalah sistem symbol, sistem keyakinan, sistem nilai, dan sistem perilaku yang terlembagakan, yang semua itu berpusat pada persoalan-persoalan yang dihayati sebagai yang paling maknawi (ultimate meaning).

GLock \& Stark (dalam Ancok, 1989) membagi lima aspek dari religiusitas, yaitu:

1. Dimensi keyakinan (ideologis) : Yaitu tingkat penerimaan seseorang terhadap hal-hal yang dogmatis dalam agamanya, misalnya mengenai adanya Tuhan, Malaikat, dll. Di dalam keberislaman, isi dimensi keimanan menyangkut keyakinan tentang Allah, para malaikat, Nabi atau Rasul, kitab-kitab Allah, surga dan neraka, serta qadha' dan qadar.

2. Dimensi praktek agama (ritualistik) : Yaitu tingkat pelaksanaan akan kewajiban-kewajiban ritual dalam agamanya, misalnya sholat, puasa, zakat,dll.

3. Dimensi penghayatan (eksperiensial) : Dimensi ini berkaitan dengan pengalaman keagamaan, perasaan-perasaan, persepsi-persepsi, dan sensasi-sensasi yang dialami seseorang atau didefinisikan oleh suatu kelompok keagamaan (atau suatu masyarakat) yang melihat komunikasi, walaupun kecil, dalam suatu esensi ketuhanan, yaitu dengan Tuhan, kenyataan terakhir, dengan otoritas transendental.

4. Dimensi pengalaman (konsekuensial) : yaitu tingkat pengetahuan seseorang tentang ajaran agamanya, misalnya mengenai sifat-sifat Tuhan. Dimensi ini menunjuk pada seberapa tingkatan muslim berperilaku dimotivasi oleh ajaran-ajaran agamanya, yaitu bagaimana individu berelasi dengan dunianya, terutama dengan muslim lainnya.

5. Dimensi pengetahuan agama (intelektual) : Dimensi ini mengacu pada identifikasi akibat-akibat keyakinan keagamaan, praktek, pengalaman, dan pengetahuan seseorang dari hari ke hari. Istilah "kerja” dalam pengetahuan teologis digunakan disini.

\section{Intensitas Perilaku menyontek}

Intensi diartikan sebagai niat seseorang untuk melakukan perilaku didasari oleh sikap dan norma subjektif terhadap perilaku tersebut. Fishbein \& Ajzen juga menambahkan bahwa intensitas perilaku merupakan determinan terdekat dengan perilaku yang dimaksud dan merupakan prediktor tunggal terbaik bagi perilaku yang akan dilakukan seseorang (Fishbein \& Ajzen, 1975:288). Perilaku menyontek (Cheating) adalah strategi yang digunakakan siswa untuk meningkatkan kinerja (dalam hal ini yang dimaksud adalah nilai) mereka dengan cara yang tidak benar (Anderman, dkk. 1998). Thornberg (dalam Mujahidah, 2009:178) memahami menyontek sebagai pengambilan atau permintaan bantuan yang tidak legal dalam tes.

Kata menyontek sama dengan Cheating. Beliau mengutip pendapat Bower (dalam Rahmat, 2012:5) yang mengatakan Cheating adalah perbuatan yang menggunakan cara-cara yang tidak sah untuk tujuan yang sah atau terhormat yaitu mendapatkan keberhasilan dengan cara-cara yang tidak jujur.

Belum ada teori yang membahas mengenai intensi menyontek, sehingga aspek-aspek intensi menyontek diperoleh dari bentuk-bentuk perilaku menyontek menurut Klausmeimer, yang disertai dengan aspek-aspek intensitas menurut Fishbein dan Ajzen, 1975:292). Intensi sebagai niat untuk melakukan suatu perilaku demi mencapai tujuan tertentu memiliki empat aspek, yaitu:

1. Perilaku (Behavior) : Yaitu perilaku spesifik yang nantinya akan diwujudkan. Pada konteks menyontek, perilaku spesifik yang akan diwujudkan merupakan bentuk-bentuk perilaku menyontek yaitu menggunakan catatan jawaban sewaktu ujian atau ulangan, mencontoh jawaban siswa lain, memberikan jawaban yang talah selesai pada teman, dan mengelak dari aturan-aturan (Abramovits dalam Mujahidah, 2009:179).

2. Sasaran (target) : Yaitu objek yang menjadi sasaran perilaku. Objek yang menjadi sasaran dari perilaku spesifik dapat digolongkan menjadi tiga, yaitu orang tertentu atau objek tertentu (particular object), sekelompok orang atau sekelompok objek (a class of object), dan orang atau objek pada umumnya (any object) (Fishbein dan Ajzen, 1975:292). Pada konteks menyontek, objek menjadi sasaran perilaku 
dapat berupa catatan jawaban, buku, telepon genggam, kalkulator, maupun teman (Davids dalam Mujahidah 2009:179).

3. Situasi (situation): Yaitu situasi yang mendukung untuk dilakukannya suatu perilaku (bagaimana dan dimana perilaku itu akan diwujudkan) (Fishbein dan Ajzen, 1975:292). Situasi dapat pula diartikan sebagai lokasi terjadinya perilaku.

\section{METODE PENELITIAN}

Penelitian ini dilakukan di MTs Mazra'atul Ulum Paciran - Lamongan.Adapun yang menjadi subjek penelitian adalah siswa-siswi kelas VII, VIII dan IX yang berjumlah 464 siswa. Teknik pengambilan sampel yang digunakan adalah probability Samplingyang berupa proportionate stratified random sampling dan peneliti mengambil $15 \%$ untuk pengambilan sampelnya sehingga diperoleh sebanyak 71 siswa.

Metode pengumpulan data dalam penelitian ini menggunakan alat ukur berupa skala psikologi dengan jenis skala likert. Ada tiga skala psikologi yang digunakan:

1. Skala efikasi diri: Efikasi diri adalah keyakinan terhadap kemampuan yang dimiliki dan kemantapan diri dalam menyelesaikan tugas tertentu yang terdiri dari tiga dimensi, yaitu: level (tingkatan), strength (kekuatan), dan generality (umum). Semakin tinggi skor Efikasi diri yang diperoleh menunjukkan semakin tinggi efikasi diri pada siswa, dan sebaliknya.

2. Skala Reigiusitas: Religiusitas dapat diartikan sebagai internalisasi agama dalam diri seseorang yang terlihat melalui pengetahuan dan keyakinan seseorang akan agamanya serta dilaksanakan dalam kegiatan peribadatan dan perilaku kesehariannya meliputi keyakinan agama, praktek agama, pengalaman agama, dan pengalaman/ konsekuensi. Semakin tinggi skor religiusitas yang diperoleh menunjukkan semakin positif religiusitas pada siswa, dan sebaliknya.

3. Skala intensitas perilaku menyontek: Menyontek adalah perilaku seseorang untuk melakukan suatu perbuatan curang atau tidak jujur sewaktu ulangan/ujian/tes dengan menggunakan catatan jawaban sewaktu ujian ulangan, mencontoh jawaban teman, memberikan jawaban yang telah selesai pada teman, mengelak dari aturan-aturan dalam situasi dan waktu tertentu. Diukur dengan skala Intensi menyontek yang disusun berdasarkan bentuk-bentuk perilaku menyontek menurut Klausmeimer dan aspekaspek intensi menurut Fishbein dan Ajzen. Semakin tinggi skor perilaku menyontek yang diperoleh menunjukkan semakin tinggi pula niat subjek untuk menyontek, dan sebaliknya.

Untuk menguji validitas digunakan teknik korelasi product moment dari Pearson. Pedoman untuk menentukan validitas item adalah dengan menggunakan standar 0.3 , sehingga aitemaitem yang memiliki $r_{x y}<0.3$ dinyatakan gugur. Sedangkan jika $r_{x y}>0.3$ maka aitem tersebut dinyatakan valid (Saifudin, 2007:5). Sedangkan Reliabilitas suatu konstruk variabel dikatakan baik jika memiliki Cronbach's alpha > dari 0.60 (Saifudin, 2007: 8).

\section{HASIL DAN PEMBAHASAN}

Berdasarkan hasil analisis dengan dengan menggunakan teknik product moment, diperoleh hasil sebagai berikut:

Table 1 Hasil korelasi

\section{Correlations}

\begin{tabular}{lllll}
\hline & & Efikasi & Religiusitas & Menyontek \\
\hline Efikasi & Pearson Correlation & 1 & $.608^{* *}$ & $-.484^{* *}$ \\
& Sig. (1-tailed) & & .000 & .000 \\
& $\mathrm{~N}$ & 71 & 71 & 71 \\
\hline Religiusitas & Pearson Correlation & $.608^{* *}$ & 1 & $-.369^{* *}$ \\
& Sig. (1-tailed) & .000 & & .001 \\
& $\mathrm{~N}$ & 71 & 71 & 71 \\
\hline Menyontek & Pearson Correlation & $-.484^{* *}$ & $-.369^{* *}$ & 1 \\
& Sig. (1-tailed) & .000 & .001 & 71 \\
\hline
\end{tabular}

**. Correlation is significant at the 0.01 level (1-tailed). 
Tabel di atas menjelaskan bahwa korelasi antara Efikasi Diri dan Religiusitas dengan Intensi Perilaku menyontek ditunjukkan dengan hasil koefesien korelasi efikasi diri 1.000 , koefesien korelasi religiusitas 0.608 dan koefesien korelasi -0.369 dengan sig $=0.000<0.05$. hal ini menunjukkan ada hubungan yang signifikan antara efikasi diri dan religiusitas dengan intensi perilaku menyontek siswa. Berdasarkan penelitian yang telah dilakukan oleh peneliti menghasilkan efikasi diri dan religiusitas berhubungan dengan intensi perilaku menyontek. Temuan ini menunjukkan bahwa efikasi diri dan religiusitas dianggap dapat mendukung secara efektif dalam menurunkan intensi perilaku menyontek.

Dalam penelitian ini, aspek efikasi diri lebih besar hubungannya dengan aspek intensitas perilaku menyontek. Sedangkan aspek religiusitas lebih kecil hubungannya terhadap aspek intensitas perilaku menyontek. Hal ini dapat dilihat pada hasil koefesien korelasi aspek efikasi diri 1.000, sedangkan untuk hasil koefesien korelasi aspek religiusitas 0.608.

Pada penelitian ini, variabel efikasi diri dan religiusitas menyumbang $49.3 \%$ terhadap intensi perilaku menyontek siswa di MTs Mazra'atul Ulum Paciran.sedangkan $50.7 \%$ berasal dari variabel lain yang mempunyai hubungan terhadap intensi perilaku menyontek. Ada beberapa variabel yang mempengaruhi perilaku menyontek yaitu: (1) Faktor situasional (Tekanan untuk mendapat nilai tinggi, kontrol atau pengawasan selama ujian, kurikulum, pengaruh teman sebaya, ketidaksiapan mengikuti ujian, dan iklim akademis di institusi pendidikan). (2) Faktor personal (Kurang percaya diri, selfesteem dan need for approval, ketakutan terhadap kegagalan dan kompetensi dalam memperoleh nilai atau peringkat akademis). (3) Faktor demografi (Jenis kelamin, usia, nilai, riwayat pendidikan sebelumnya, jurusan dan perkembangan moral, status perkawinan, keterlibatan organisasi, bekerja sambil sekolah, banyaknya mata pelajaran.). (4) Faktor perkembangan teknologi; perkembangan

\section{DAFTAR PUSTAKA}

Alawiyah, H. 2011. Pengaruh Self-Efficacy, Konformitas, dan Goal Orientation terhadap Perilaku Menyontek (Cheating) Siswa MTs Al-Hidayah Bekasi. Skripsi.Fakultas Psikologi Universitas Islam Negeri Syarif Hidayatullah, Jakarta. Tidak diterbitkan.

Ancok, Djamaluddin \& Fuad, N. S. 2011.Psikologi Islam. Yogyakarta: Pustaka Belajar. teknologi membuat teknik menyontek semakin berkembang dan semakin mudah (Born \& Park dalam Mujahidah, 2009:185).

Sikap terhadap menyontek terbentuk berdasarkan informasi yang diterima mengenai perilaku menyontek, jika informasinya positif, hasil evaluasi afektifnya akan menolak atau menganggap perilaku menyontek adalah perbuatan yang dilarang maka sikapnya menjadi negatif. Perbedaan sikap tersebut selanjutnya akan mendorong terjadinya perbedaan dalam perilaku menyontek dikalangan siswa. Dengan demikian, bervariasinya tingkat keimanan diatara siswa secara konsisten akan terefleksikan dalam bervariasinya sikap mereka terhadap menyontek dan perilaku menyonteknya. Siswa yang memiliki tingkat keimanan yang rendah akan cenderung memiliki sikap yang positif terhadap menyontek.

\section{KESIMPULAN}

Siswa MTs Mazra'atul Ulum Paciran-Lamongan memiliki tingkat efikasi diri dengan kategori sedang yang berjumlah 49 siswa dengan prosentase $69.0 \%$, siswa memiliki tingkat religiusitas dengan kategori sedang yang berjumlah 46 siswa dengan prosentase $64.8 \%$ dan siswa memiliki intensi perilaku menyontek kategori sedang yang berjumlah 46 siswa dengan prosentase 64.8.

Hasil dari penelitian menunjukkan bahwa adanya hubungan negative atara efikasi diri dan religiusitas dengan intensitas perilaku menyontek pada siswa di MTs Mazra'atul Ulum Paciran-Lamongan.Efikasi diri mempunyai hubungan lebih besar dengan intensitas perilaku menyontek.Sedangkan untuk aspek religiusitas mempunyai hubungan yang lebih kecil dengan intensitas perilaku menyontek. Hal ini ditunjukkan pada hasil koefesien korelasi efikasi (rxy) diri lebih besar yaitu sebesar -0.484 dengan nilai $P=0.000$. sedangkan untuk hasil koefesien korelasi (rxy) religiusitas hanya sebesar -0.369 , dengan nilai $\mathrm{P}=0.001$ terhadap intensitas perilaku menyontek.

Azwar, saifudin. 2007. Reliabilitas dan validitas. Yogyakarta: Pustaka belajar.

Bandura, A. 1986. Social Foundations of Thought and Action: A Social Cognitive Theory. New Jersey: Prentice Hall.

1997. Self-Efficacy, The Exercise Control. New York: Stanford University.

Farhah, S. 2011. Hubungan Religiusitas dengan Perilaku Prososial Mahasiwa Pengurus Lembaga 
Dakwah Kampus UIN Syarif Hidayatullah Jakarta. Sripsi.Fakultas Psikologi Universitas Islam Negeri Syarif Hidayatullah, Jakarta. Tidak diterbitkan. Hartanto, D. 2012.

Bimbingan \& Konseling: Menyontek Mengungkap Akar Masalah dan Solusinya. Jakarta: Indeks. Echols, J.M. \& Shadily, H. 2003. Kamus Inggris Indonesia. Jakarta: PT. Gramedia. Fetzer Institute and national Institute on Aging Working Group. 1999.
Multidimension Measurement of religiousness, Spiritually for Use in Health Research. Fetzer Institude in Collaboration with the Nasionallnstitude on Aging. Kalamazoo. Fishbein, M. \& Ajzen, I. 1975. Belief Attitude, Intention and Behavior: AnIntroduction to Theory and Research. California: AddisonWesleyPublishing.

Mujahidah. 2009. Perilaku Menyontek Laki-Laki dan Perempuan: Studi Meta Analisis. Jurnal psikologi, vol. II, No.2.Fakultas Tarbiyah, Sekolah Tinggi Agama Islam Negeri, Samarinda. 